\title{
Inhibition of mTORC2/Akt signaling to enhance the therapeutic potential of CD8 T cells
}

\author{
Lianjun Zhang ${ }^{1 *}$, Benjamin Tschumi ${ }^{1}$, Susanne Oberle ${ }^{2}$, Markus Ruegg ${ }^{3}$, Michael Hall ${ }^{3}$, Dietmar Zehn², \\ Jean-Pierre Mach ${ }^{4}$, Alena Donda ${ }^{1}$, Pedro Romero ${ }^{1}$ \\ From 30th Annual Meeting and Associated Programs of the Society for Immunotherapy of Cancer (SITC 2015) \\ National Harbor, MD, USA. 4-8 November 2015
}

CD8 T cells mediate protective immune responses against infections and cancer. Upon infection, antigenspecific naïve CD8 $\mathrm{T}$ cells are activated and differentiate into short-lived effector (SLEC) and memory precursor cells (MPEC). The $\mathrm{T}$ cell intrinsic signaling pathways underlying this differentiation remain largely unresolved. Here we show that Rictor, the core component of mammalian target of rapamycin complex 2 (mTORC2), regulates SLEC and MPEC commitment. Rictor deficient $\mathrm{T}$ cells form enhanced memory without dampening effector function, have increased IL-2 secretion capacity and mediate more potent recall responses. Mechanistically, enhanced memory formation in the absence of functional mTORC2 was associated with transcriptional and metabolic reprogramming by Eomes and Tcf- 1 upregulation, repression of T-bet and nuclear stabilization of Foxo1. Elimination of Foxo1 reversed the increased MPECs differentiation and IL-2 production in Rictor $\mathrm{KO}$ mice. Effective $\mathrm{T}$ cell therapy against cancer depends highly on the generation of long-term persistent memory CD8 $\mathrm{T}$ cells. Our preliminary data show that Rictor deficient CD8 $\mathrm{T}$ cells show superior tumor protection effects in mouse melanoma model. Together, our study identifies mTORC2 as a central regulator of CD8 $\mathrm{T}$ cell differentiation and inhibition of mTORC2 or Akt might represent an effective strategy for both adoptive cell transfer and vaccine-based cancer therapies.

\footnotetext{
Authors' details

'Ludwig Cancer Research of University of Lausanne, Switzerland, Epalinges, Switzerland. Swiss Vaccine Research Institute, Lausanne, Switzerland, Lausanne, Switzerland. 'Biozentrum, University of Basel, Switzerland, Basel,
}

${ }^{1}$ Ludwig Cancer Research of University of Lausanne, Switzerland, Epalinges, Switzerland

Full list of author information is available at the end of the article
Switzerland. ${ }^{4}$ Department of Biochemistry, University of Lausanne, Switzerland, Epalinges, Switzerland.

Published: 4 November 2015

doi:10.1186/2051-1426-3-S2-P330

Cite this article as: Zhang et al:: Inhibition of mTORC2/Akt signaling to enhance the therapeutic potential of CD8 T cells. Journal for ImmunoTherapy of Cancer 2015 3(Suppl 2):P330.
Submit your next manuscript to BioMed Central and take full advantage of:

- Convenient online submission

- Thorough peer review

- No space constraints or color figure charges

- Immediate publication on acceptance

- Inclusion in PubMed, CAS, Scopus and Google Scholar

- Research which is freely available for redistribution

Submit your manuscript at www.biomedcentral.com/submit
() Biomed Central 